\title{
Isolation of high lipid-content strains of the marine microalgae Tetraselmis suecica for biodiesel production by flow cytometry and single-cell sorting
}

\author{
María F. Montero, Manuela Aristizábal, Guillermo García Reina \\ Centro de Biotecnología Marina \\ Muelle de Taliarte $\mathrm{s} / \mathrm{n}$ \\ Universidad de Las Palmas de Gran Canaria \\ 35214 Telde, Gran Canaria, Spain
}

Corresponding author: MF Montero

Email: $\underline{\text { nmontero@dbio.ulpgc.es }}$

Tel: 34-928454547

Fax: 34-928454490

\begin{abstract}
Biodiesel from algae is considered an alternative for a third generation of biofuels. However, most microalgae are not lipogenic during fast growth periods, but high lipid content occurs at resting stages. Microalgae biomass production for biodiesel needs continuous high volumetric and aerial yields and large amount of neutral lipid in the biomass. These requirements are similar to demanding a marathon runner to be obese. We show that by using cell-sorting capabilities of flow cytometers, in combination with the lipid-soluble fluorescent dye Nile Red, we can isolate and select cells with a high and stable lipid content. In our study we were able to select the equivalent of a stable "fat marathon runner" through three sorting events obtained from wild populations of Tetraselmis suecica
\end{abstract}

Keywords: Citometry, Fluorescence-activated cell sorting (FACS), Nile Red (NR), Neutral lipids, Tetraselmis suecica 


\section{Introduction}

Nowadays, there is growing interest on the use of microalgae as a source of biomass for alternative fuel production (Williams 2007; Chen et al 2009). Many studies aim at biodiesel production from microalgae (e.g. Pulz 2001; Dismukes et al 2008), considered as an alternative for a third generation of biofuels. Some consider microalgae to be the only renewable biofuel capable of meeting the global demand for transport fuels (Chisti 2007). Amongst other advantages, compared with traditional biofuel production based on higher plants, microalgae cultivation technology is well developed, does not compete with food production for arableland or water supply, is independent on soil fertility, and the annual yields per unit area are much greater than those for higher plants (Williams 2007). Indeed, microalgae are gaining increased scientific attention due to their potential ability to synthesize and accumulate large amounts of neutral lipids (25-50\% of dry weight), mainly in the form of triacylglycerol (TAG) (Hu et al 2008, Chen et al 2009), which is suitable for biodiesel production. Nevertheless, to achieve profitable microalgae cultures for biodiesel, the strains should combine two (apparently) antagonistic characteristics: fast growth and high TAG content. It is like searching for a "fat marathon runner".

Here we describe a method combining the use of fluorescence-activated cell sorting (FACS) and lipid-soluble fluorescent dye Nile Red (NR; McGinnis et al 1997; Elsey et al. 2007) to identify, isolate, and select cells with a higher and stable lipid content from wild (and fast growing) strains of Tetraselmis suecica.

T. suecica is considered to be a high lipid productivity strain (Rodolfi et al, 2009) with an average lipid productivity of $32 \mathrm{mg} \mathrm{L}^{-1} \mathrm{~d}^{-1}$ (Griffiths \& Harrison, 2009). Previous work carried out in our lab (unpublished results) indicates that $T$. suecica achieves a lipid productivity of $27 \mathrm{mg} \mathrm{L}^{-1} \mathrm{~d}^{-1}$, a TGA productivity of $9 \mathrm{mg} \mathrm{L}$ ${ }^{1} \mathrm{~d}^{1}$ and a biomass production of $0.20 \mathrm{~g}$ afdw $\mathrm{L}^{-1} \mathrm{~d}^{-1}$ in cultures grown in $1.5 \mathrm{~L}$ photobioreactors. This marine microalgae is between the best biomass producers and robust enough to be regarded of high potential for oil production (Chini Zittelli 2006; Rodolfi 2009). Moreover, it was observed that neutral lipids were present both during the exponential and stationary phase (Mendoza et al 2009). Therefore, we selected $T$. suecica as a suitable candidate to reach our goals, due to its fast 
growth, high source of biomass, presence of lipids during most steps of the culture evolution, and positive-response to cell staining with NR.

\section{Material and methods}

T. suecica was obtained from the "Banco Nacional de Algas" (BNA) culture collection (strain BNA 10_037; Centro de Biotecnología Marina, University of Las Palmas, Canary Islands, Spain). Wild algal strain cultures were grown with MBA medium (Table 1), in a $1.5 \mathrm{~L}$ polyethylene terephthalate (PET) column photobioreactor $(\varnothing=9 \mathrm{~cm}$; height $=31 \mathrm{~cm})$ under greenhouse sunlight conditions (temperature range between 20,0 and $30,4{ }^{\circ} \mathrm{C}$; mean PAR doses of $11870 \pm 1795 \mathrm{~kJ}$ $\mathrm{m}^{-2} \mathrm{~d}^{-1}$ ). Mixing was provided by continuous air bubbling. $\mathrm{CO}_{2}$ was injected 9 times per day in 50 seconds-pulse intervals.

Fluorescence-activated cell sorting was carried out using an Epics-Altra cytometer (Beckman-Coulter) equipped with a $15 \mathrm{~mW}$ air-cooled $488 \mathrm{~nm}$ argon-ion laser. Upon excitation by the laser, NR exhibits yellow fluorescence when dissolved in neutral lipids, and reaches its peak in emision intensity at $570 \mathrm{~nm}$ (Elsey et al 2007). NR fluorescence and chlorophyll autofluorescence were detected by the optical system in the FL3 channel $(575 \pm 25 \mathrm{~nm}$ bandpass filter) and FL5 channel (675 $\mathrm{nm} \pm 40 \mathrm{~nm}$ bandpass filter), respectively.

Sorting was performed at high pressure (31.4-31.5 psi), using a $70 \mu \mathrm{m}$ nozzle, a drop drive frequency of about $59 \mathrm{KHz}$, and a flow rate ranging between 15000 and 20000 cells s $\mathrm{s}^{-1}$. Instrumental alignments corrections were daily checked, based on fluorescent bead signals (10 $\mu \mathrm{m}$ Flow- check Fluorospheres, Beckman Coulter) represented in Forward Scatter versus Side Scatter plots and fluorescence histograms. Next, the setting up of the sort delay and the sort recovery were controlled by counting with an epifluorescence microscope the number of sorted beads deposited on a slide. The recovery was consistently $>85 \%$.

Once the checking process was finished, the selection process started with wild samples of fast-growing T. suecica. 3 to $4 \mathrm{ml}$ of cell suspensions $\left(20 \times 10^{6}\right.$ cells $\mathrm{ml}^{-1}$ ) were stained with $10 \mu \mathrm{l}$ per $\mathrm{ml}$ of working solution of NR and acetone (0.1 $\mathrm{mg} / \mathrm{ml}$ ) concluding with $3 \mu \mathrm{M}$ final concentration. The mixture was vortexed then incubated for 15 minutes at $37{ }^{\circ} \mathrm{C}$ in darkness. Meanwhile, unstained cells were 
used as an autofluorescence control displaying yellow and red fluorescence (by FL3 and FL5 channels, respectively) from bivariate scatter plots (Forward Scatter versus FL5 and FL5 versus FL3) and two histograms (FL5 and FL3) on the computer screen.

Immediately after the incubation finished, the stained cells were analysed and the sorting criteria set-up. Sorting windows were positioned to isolate the cells with the highest relative yellow fluorescence from histogram FL3 (between 8 to 25 $\%$ of the population in 10 strains), corresponding to the extreme right tail. The first sorted cells were observed under the microscope, to verify that they contained larger amounts of lipid droplets than the whole un-sorted population. During the sorting process the cells were poured into Falcon tubes, containing $500 \mu \mathrm{l}$ of MBA or seawater, depending on the treatment applied, as explained later. The cell cultures were transferred to glass conical tubes and placed in an indoor culture chamber with a light intensity of $75 \mu \mathrm{mol}$ photons $\mathrm{m}^{-2} \mathrm{~s}^{-1}$ in a 12-hour light/dark cycle at $24^{\circ} \mathrm{C}$, . Cell cultures were grown adding media MBA until the next sorting process.

To decide the best methodology, several treatments were applied to the wild strain to assess the cultivability of the isolated cells, based on their viability and recovery during the first 24 hours after sorting (Figure 1). The alternative treatments were: (1) using either a commercial sheath fluid (Isoton ${ }^{\circledR}$ II; Beckman Coulter) or GF/F-filtered seawater as sheath fluid in the cytometer; (2) resuspending the cells after extracting the supernatant sheath fluid (post-sorting) in fresh MBA media or in filtered seawater; (3) keeping isolated cells on seawater (from the sheath fluid) or in fresh MBA during the initial 24 hours post-sorting period. In all cases isolated cells were concentrated by soft centrifugation (1 min $300 \mathrm{~g}$ ) to yield a $1 \mathrm{ml}$ inoculum before transferring to glass tubes. 24 hours later, $500 \mu \mathrm{l} \mathrm{MBA}$ were added to the the cells, and $300 \mu \mathrm{l}$ were added the following days, although trying to not dilute the cells in excess. Simultaneously, the cells were gently mixed and observed under the microscope for motility, growth and viability after 24 hours.

The possible toxic effect of the Isoton II solution (distributed as sheath fluid for many sorter equipments) was evaluated by quantifying the cells viability under several Isoton dilutions treatments (Figure 2). $1 \mathrm{ml}$ of $T$. suecica culture (with a cellular density of $11 \times 10^{6}$ cell $\mathrm{ml}^{-1}$ ) was dispensed into each of 9 Falcon tubes. 
Triplicate samples of 3,4 and $6 \mathrm{ml}$ Isoton were added to get 1:4, 1:5 and 1:7 dilutions. The dilution 1:4 corresponds to the usual one obtained in the Epics-Altra cytometer during the sorting process at cell densities of $20 \times 10^{6}$ cells ml-1. After 30 minutes incubation (the average time that cells are immersed in Isoton), the tube cells were concentrated by low centrifugation ( $1 \mathrm{~min}$ at $300 \mathrm{~g}$ ), and the Isoton was extracted. Then the pellet was resuspended in $2 \mathrm{ml}$ of filtered seawater. Finally, a FDA (Fluorescein DiAcetate) viability cell control was performed to all tubes (as indicated in Coder, 1997). We used a fresh solution (1:10 in water), prepared from a stock solution of FDA ( $1 \mathrm{mg} \mathrm{ml}^{-1}$ in acetone, kept at $\left.4^{\circ} \mathrm{C}\right) .20 \mu \mathrm{l}$ of this solution were added to $1 \mathrm{ml}$ of each of the 9 Falcon tubes containing the resuspended cells and incubated for $15 \mathrm{~min}$ at $37^{\circ} \mathrm{C}$. The samples were immediately analyzed in a Quanta flow cytometer (Beckman- Coulter) at $525 \pm 25 \mathrm{~nm}$ (excitation at $480 \mathrm{~nm}$ ) to quantify the viable cells.

\section{Results and discussion}

The best experimental conditions for sorting and successful growing of high lipidic strains were achieved with the following protocol: (1) using seawater as sheath fluid, which avoids the Isoton toxic effect on cells, and makes unnecessary the centrifugation step to extract the Isoton after sorting (Figure 1), (2) isolating and sorting of ten percent of the population with the highest FL3 signal (Figure 3), and (3) maintaining sorted cells initially in seawater, by adding 300-500 $\mu \mathrm{l} \mathrm{MBA}$ media after 24 hours. Microscopic inspection of sorted single cells following these three steps showed that most of the sorted cells were motile and not visibly damaged. These cells were satisfactorily used for re-growth of new algal strains. We obtained an average cell recovery of about $65 \%$ with respect to the viable cells $(80 \%)$ significantly higher than the 20 to $30 \%$ reported by Sensen et al (1993) for phytoplankton flagellates. Other microorganisms as bacteria gave variable results, in the range of 22 to $85 \%$ (Resina-Pelfort et al 2001).

We found that, under our experimental conditions, the optimal concentration of NR both for staining the cells and keeping them active was $3 \mu \mathrm{M}$, at cell densities about $15-20 \times 10^{6}$ cells $\mathrm{ml}^{-1}$. This concentration is five times lower than that used by other authors $(15 \mu \mathrm{M})$ who reported toxic effects of the dye at cell densities of $10^{5}$ - 


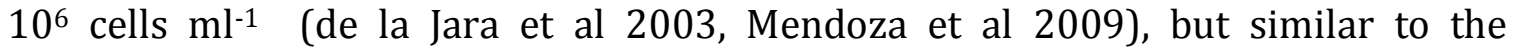
concentration used by others, like Lopes da Silva et al (2009). We found a strong linear correlation $\left(\mathrm{r}^{2}=0.81, \mathrm{n}=18\right)$ between the fluorescence signal FL3 of cells stained with NR and the triacylglicerol content of the same cells, measured with a commercial enzymatic colorimetric test (Triglycerid L-Type, Wako Chemicals $\mathrm{GmbH})$, using triolein as standard. A similarly strong correlation $\left(\mathrm{r}^{2}=0.87, \mathrm{n}=18\right)$ between FL3 and neutral lipids estimated by gravimetry was reported by Mendoza et al (2009) for the same strain of T. suecica (BNA-10037). Other authors have also reported highly significant correlations between the NR fluorescence and total microalgal lipid content (Chen et al 2009; Cooksey et al 1987; de la Jara et al 2003; da Silva et al 2009); thus, supporting the view that the dye is a useful proxy for quantification of lipids in microalgae in order to achieve sorting of hyperlipidic strains.

Our experiments analyzing the toxicity effects of the Isoton on isolated $T$. suecica clearly indicate that cell viability is reduced from $79 \%$ (in the cell control, from the photobioreactor) to $34 \%, 25 \%$, and $15 \%$ at dilutions $1: 4,1: 5$, and $1: 7$, respectively (Figure 2). These results agree with the observed absence or low cell motility under microscopy and consequently worst cell recovery. Presumably, the toxic effect is associated with some Isoton components, that have been referred in the literature to affect the recovery of flagellate microalgae (Sensen et al 1993), bacterial cultures, and bacterioplankton (Comas and Vives-Rego, 1997; Resina Pelfort et al., 2001). Sorting requires a conductive medium that should be chosen according to the sample being analysed. In the case of seawater microalgae, the use of plain seawater, instead of the Isoton sheath-fluid, during cell sorting increased cell viability. The addition of MBA media, 24 hours after isolation, accelerated the recovery of strains with high lipid content.

The described methodology was used to obtain two generations of hyperlipidic cells from a wild strain of cells (Figure 3). The first sorting of $8 \%$ of the wild population (15-20 x106 cells ml-1) exhibited a mean fluorescence FL3 of 0.5 (29.8 HPCV). After 26 days from the first sorting event, the algae yielded (for 1.2 x106 cells ml-1) a mean FL3 of 1.0 (17.3 HPCV). A subsequent second sorting (38 days after) yielded a mean FL3 of 2.3 (10.3 HPCV). The first isolation must be obtained from high cellular densities, being very selective (less than $10 \%$ of the 
population; see the arrow indication in the cytogram). Following these conditions, the mean lipid signal quadruplicates at the third generation of our experiments (from 0.5 to 2.3).

We measured an average growth rate $(\mu)$ of $0.39 \pm 0.07$ for our isolated $T$. suecica cells, corresponding to a mean doubling time of $43 \mathrm{~h}$. This value is only slightly higher than the average doubling time (about $38 \mathrm{~h}$ ) estimated by Griffiths \& Harrison (2009) for T. suecica in a recent review. Considering our estimated mean doubling times, the FL3 signal for the second and third generations is obtained after 14 and 21 cell divisions, respectively. Therefore, the mean lipid signal (2.3) is obtained after more than 30 cell divisions from the wild population, which supports the idea of a stable signal in the population. Our results achieved after three generations of $T$. suecica provide a promising step in isolating new strains of microalgae yielding large amounts of desirable neutral lipids. However, unlike $T$. suecica, the thick and rigid cell walls of many of these algae hampers NR to enter the cell and stain the neutral lipids. Recently, Chen et al (2009) have improved the NR method gaining in effectiveness and efficiency. This improvement may open the possibility to isolate and culture other oleaginous green microalgae (like Nannochloropsis or Chlorella ) with great potential on biodiesel production, due to their high tryacylglycerol content, while combining the NR technique with FACS as we have described in this study.

\section{Acknowledgements}

This work has been supported by the "Consorcio Estratégico Nacional de Investigación Técnica" (CENIT) - "Proyecto de Investigación para el Impulso del Biodiesel en España" (PIIBE), of the Spanish Government (coordinated by RepsolYPF). We would like to thank Dr J.L. Gómez-Pinchetti for his thoughtful comments and advice during the development of this study. 


\section{References}

Chen W, Zhang C, Song L, Sommerfeld M, Hu Q (2009) A High throughput Nile red method for quantitative measurement of neutral lipids in microalgae. J Microbiol Methods 77: 41-47

Chisti Y (2007) Biodiesel from microalgae. Biotecnol Adv 25:294-306

Chini Zitelli G, Rodolfi L, Biondi N, Tredici MR (2006) Productivity and photosynthetic efficiency of outdoor cultures of Tetraselmis suecica in annular columns. Aquaculture 261:932-943.

Coder DM (1997) Assesment of cell viability. Curr Protoc Cytom: 9.2.1-9.2.14

Comas J, Vives-Rego J (1997) Assesment the effects of gramicidin, formaldehyde and surfactants on Escherichia coli by flow cytometry using nucleic acid and membrane potential dyes. Cytometry 29: 58-64

Cooksey KE, Guckert JB, Williams SA, Callis PR (1987) Fluorometric determination of the neutral lipid-content of microalgal cells using nile red. J Microbiol Methods 6: 333-345

de la Jara A, Mendoza H, Martel A, Molina C, Nordstro L, de la Rosa V, Díaz R (2003) Flow cytometric determination of lipid content in a marine dinogflagellate Cryptecodinium cohnii. J Appl Phycol 15: 433-438

Dismukes C, Carrieri D, Bennette N, Ananyev GM, Posewitz MC (2008) Aquatic phototrophs: efficient alternatives to land-based crops for biofuels. Curr Opin Biotechnol 19: 235-240

Elsey D, Jameson D, Raleigh B, Cooney MJ (2007) Fluorescent measurement of microalgal neutral lipids. J Microbiol Methods 68: 639-642.

Grffiths MJ, Harrison STL ( 2009) Lipid productivity as a key characteristic for choosing algal species for biodiesel production. J App Phycol 21: 493-507

Hu Q, Sommerfeld M, Jarvis E, Ghirardi M, Posewitz M, Seibert M, Darzins A (2008) Microalgal triacylglycerols as feedstocks for biofuel production: perspectives and advances. Plant J 54: 621-639

Lopes da Silva T, Amarelo Santos C, Reis A (2009) Multi-parameter flow cytometry as tool to monitor heterotrophic microalgal batch fermentations for oil production towards biodiesel. Biotechnol Bioprocess Eng 14:330-337 
McGinnis KM, Dempster TA, Sommerfeld MR (1997) Characterization of the growth and lipid content of the diatom Chaetoceros muelleri. J Appl Phycol 9: 19-24

Mendoza-Guzmán H, De la Jara A, Carmona-Duarte L, Freijanes- Presmanes K (2009) Estimate by means of flow cytometry of variation in composition of fatty acids from Tetraselmis suecica in response to culture conditions. Aquacult Int 18:189199

Pultz 0 (2001) Photobioreactors: production systems for phototrophic microorganisms. Appl Microbiol Biotechnol 57: 287-297

Resina-Pelfort O, Comas-Riu J, Vives-Rego J (2001) Effect of deflected droplet electrostatic cell sorting on the viability and exoproteolytic activity of bacterial cultures and marine bacterioplankton. System Appl Microbiol 24: 31-36

Rodolfi L, Zittelli GC, Bassi N, Padovani G, Biondi N, Bonini G, Tredici MR (2008) Microalgae for oil: strain selection, induction of lipid synthesis and outdoor mass cultivation in a low-cost photobioreactor. Biotechnol Bioeng 102:100-112

Sensen CW, Heimann K, Melkonian M (1993) The production of clonal and axenic cultures of microalgae using fluorescence -activated cell sorting. Phycol 28: 9397.

Williams PJLeB (2007) Biofuel: microalgae cut the social and ecological costs. Nature 450: 478 
Table 1. Recipe of the MBA medium (seawater; salinity 37 PSU, conductivity $68 \mathrm{~ms}$ )

\begin{tabular}{lcc}
\hline Compound & $\begin{array}{c}\text { Concentrati } \\
(\mathrm{mM})\end{array}$ & $\begin{array}{c}\text { Quantity } \\
(\mathrm{g} / \mathrm{L})\end{array}$ \\
\hline $\mathrm{KNO}_{3}$ & 30 & 3 \\
$\mathrm{KH}_{2} \mathrm{PO}_{4}$ & 3 & 0.4 \\
$\mathrm{MgSO}_{4} * 7 \mathrm{H}_{2} \mathrm{O}$ & 1 & 0.25 \\
$\mathrm{Na}_{2} \mathrm{EDTA}$ & 0.3 & 0.13 \\
$\mathrm{FeSO}_{4} * 7 \mathrm{H}_{2} \mathrm{O}$ & 0.3 & 0.08 \\
$\mathrm{MnCl}_{2} \cdot 4 \mathrm{H}_{2} \mathrm{O}$ & $9.110^{-4}$ & $1.810^{-4}$ \\
$\mathrm{ZnCl}_{2}$ & $3.810^{-4}$ & $5,210^{-5}$ \\
$\mathrm{Na}_{2} \mathrm{MoO}_{4} .2 \mathrm{H}_{2} \mathrm{O}$ & $2.610^{-4}$ & $6,310^{-5}$ \\
$\mathrm{CoCl}_{2} \cdot 6 \mathrm{H}_{2} \mathrm{O}$ & $7.710^{-5}$ & $1,810^{-5}$ \\
\hline
\end{tabular}




\section{Figure captions}

Figure 1. Effect of maintaining isolated cells either in seawater (SW) or MBA media, during the first 24 hours after sorting in different experiments. (a) MBA was added after the first $24 \mathrm{~h}$. (b) MBA was added from the beginning, after sorting.

Figure 2. Toxicity effect of several isoton dilutions on cell viability of $T$. suecica. Dilution 1:4 (1 $\mathrm{ml}$ of culture in $4 \mathrm{ml}$ total) corresponds to the usual one obtained in the Epics-Altra cytometer during the sorting process at cell densities of $20 \times 10^{6}$ cells $\mathrm{ml}^{-1}$ (see text for details).

Figure 3. Isolation and sorting of high-lipidic strains of T. suecica during two consecutive steps. The first sorting (10\% of the population) was obtained from a wild population (15-20 x106 cells ml-1) cultured in a photobioreactor under greenhouse sunlight. After 26 days from the first sorting event, the algae $\left(1.2 \times 10^{6}\right.$ cells $\left.\mathrm{ml}^{-1}\right)$ yielded a mean FL3 of 1.0 (17.3 HPCV). The second sorting, 38 days after, yielded a mean FL3 of 2.3 (10.3 HPCV). The arrows indicate the sorting regions. 
Click here to download high resolution image
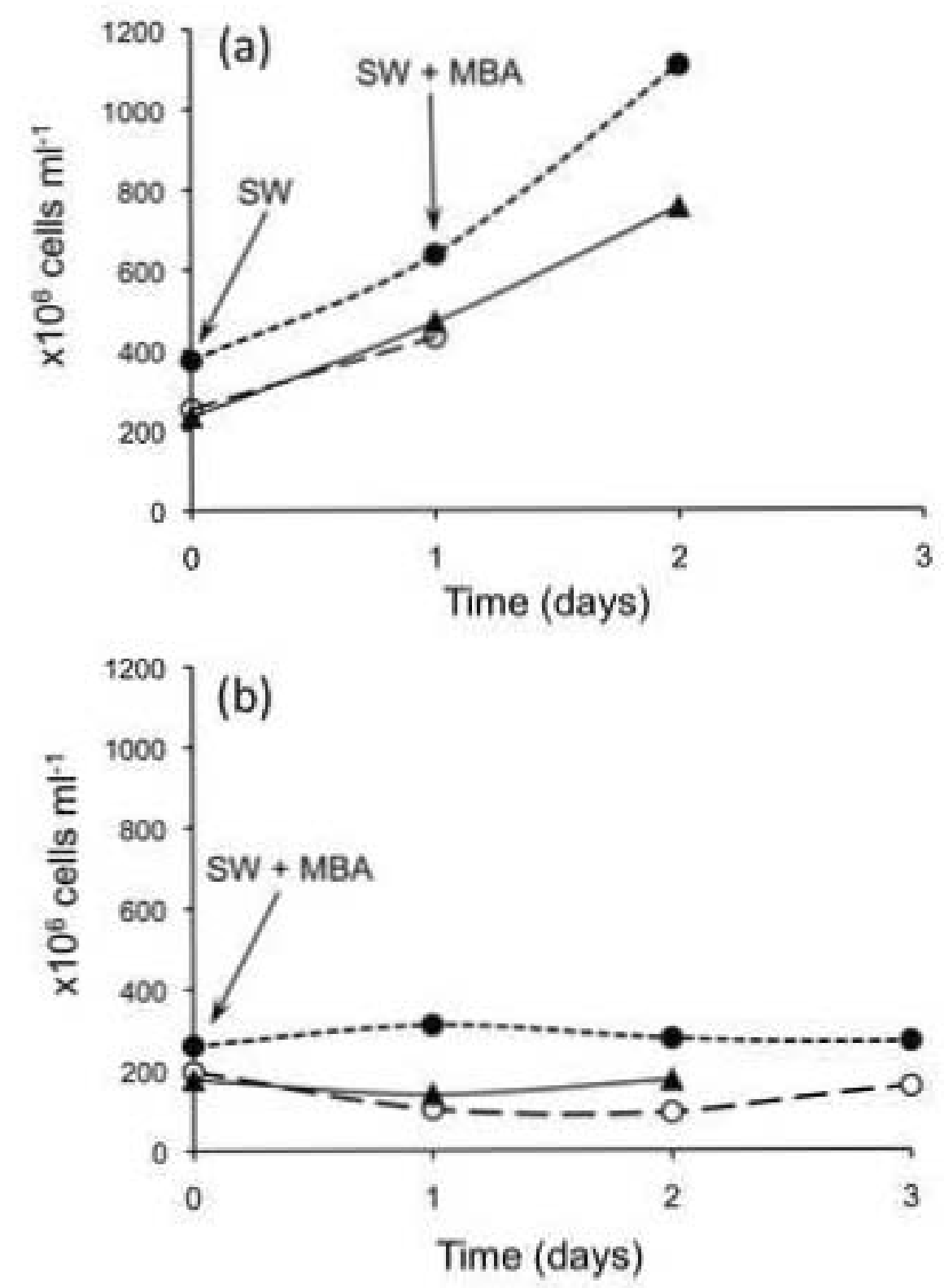

Figure 1 


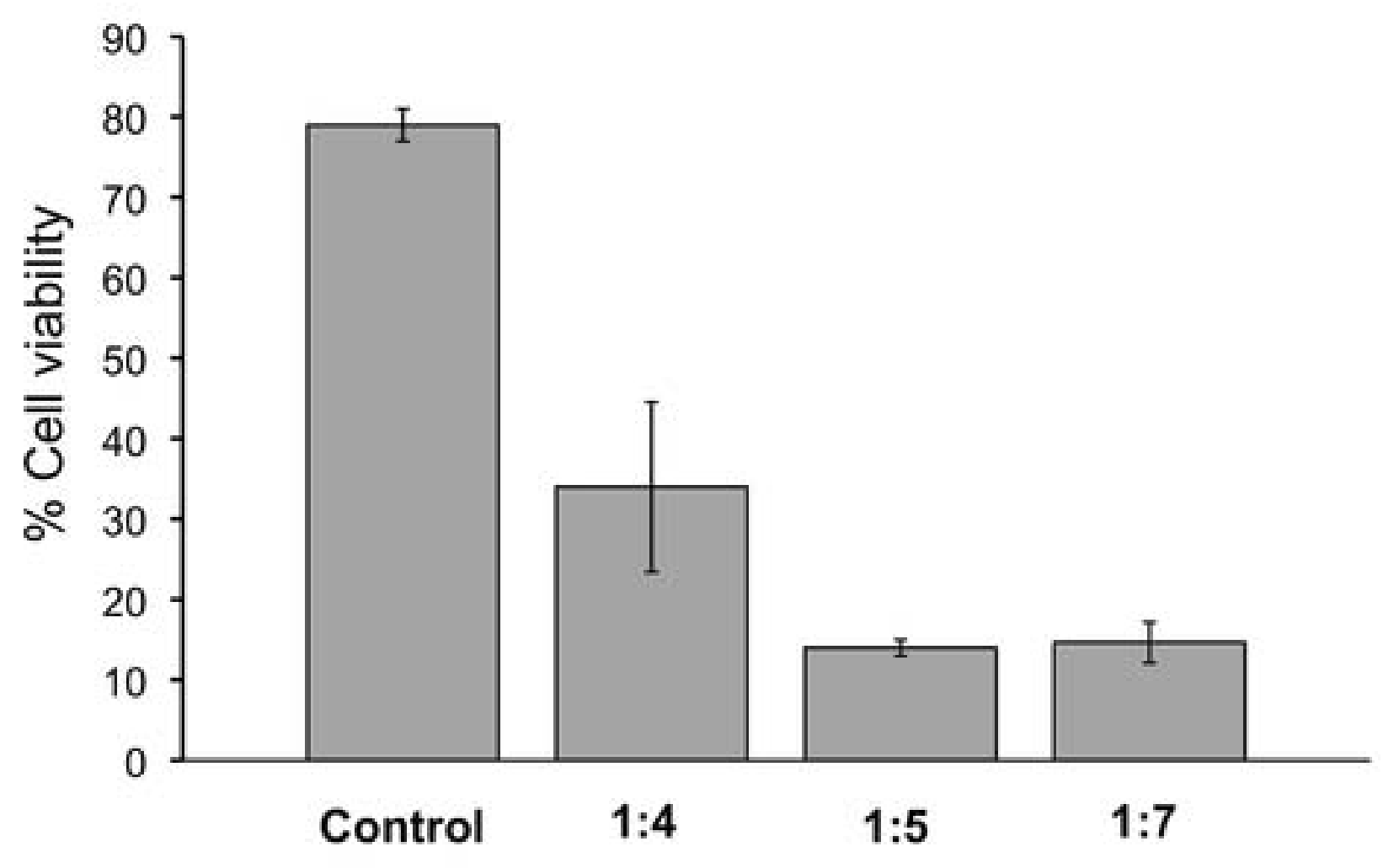

Figure 2 

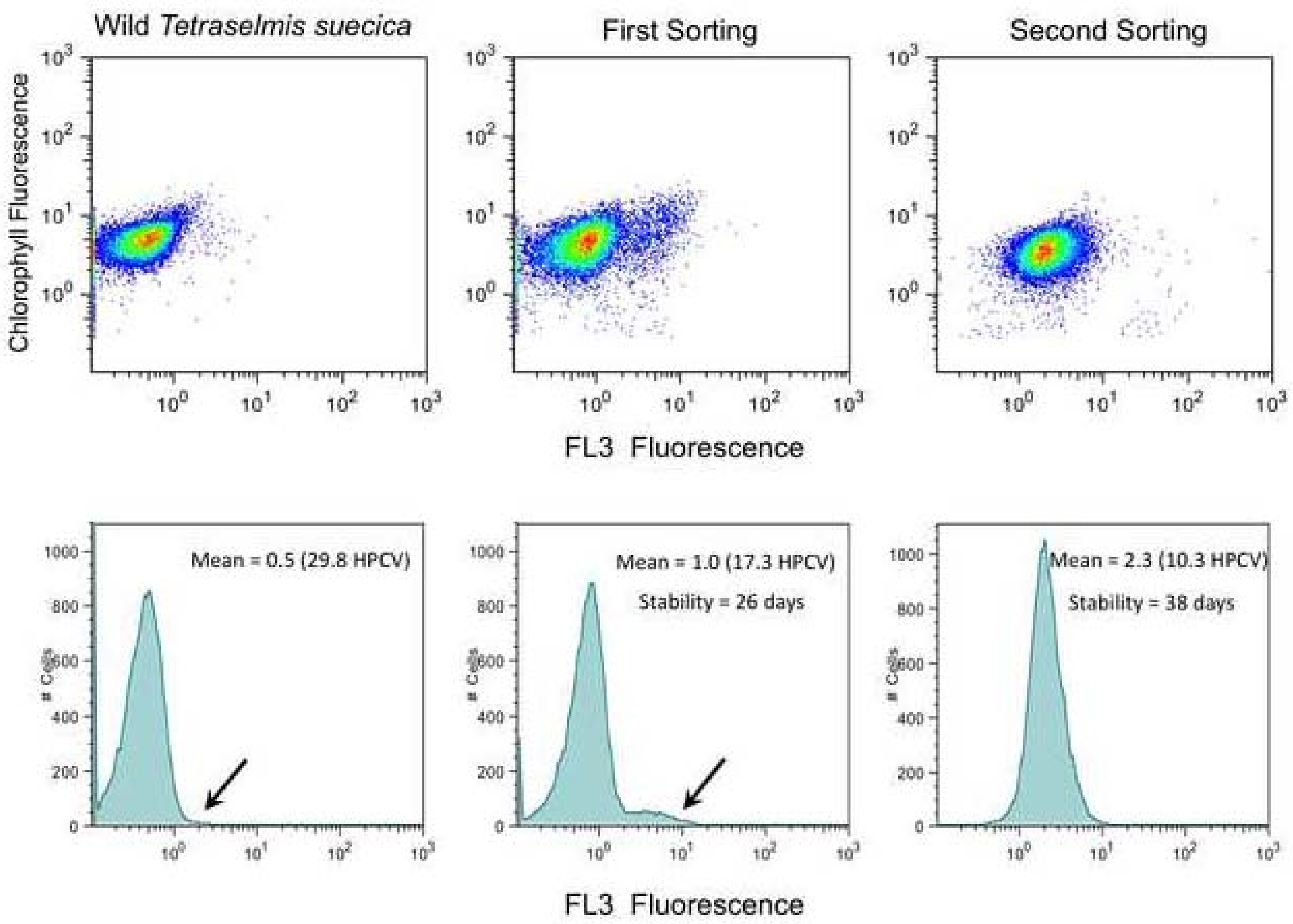

Figure 3 